\title{
Influence of topical fluoride on shear bond strength of orthodontic brackets and enamel white spot lesions formation
}

\author{
Influência do flúor tópico na resistência ao cisalhamento de braquetes \\ ortodônticos e na formação de lesões de manchas brancas no esmalte
}

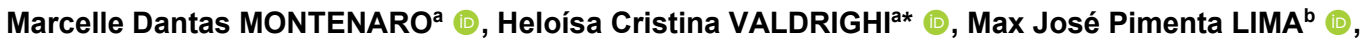 \\ Elisângela de Jesus CAMPOS $^{b}$ (1), Milton SANTAMARIA-JR ${ }^{a *}$ (1) \\ ${ }^{a} F H O$ - Fundação Hermínio Ometto, Centro Universitário, Programa de Pós-graduação em Ortodontia, Araras, SP, \\ Brasil. \\ bUFBA - Universidade Federal da Bahia, Instituto de Ciências da Saúde, Departamento de Bioquímica e Biofísica, \\ Salvador, BA, Brasil.
}

\begin{abstract}
How to cite: Montenaro MD, Valdrighi HC, Lima MJP, Campos EJ, Santamaria-Jr M. Influence of topical fluoride on shear bond strength of orthodontic brackets and enamel white spot lesions formation. Rev Odontol UNESP. 2021;50:e20210038. https://doi.org/10.1590/1807-2577.03821
\end{abstract}

\begin{abstract}
Resumo
Introdução: 0 flúor é considerado um elemento chave no processo de remineralização do esmalte dentário. Objetivo: Este estudo teve como objetivo avaliar a influência da solução tópica de fluoreto de sódio ( $\mathrm{NaF}$ ) na resistência ao cisalhamento da colagem de barquetes ortodônticos durante a formação de lesões de manchas brancas. Material e método: Sessenta dentes bovinos foram divididos em três grupos $(\mathrm{n}=20)$. Grupo 1 (Controle) - Cisalhamento imediato; Grupo 2 - Cisalhamento após ciclagem de pH; Grupo 3 - Cisalhamento após ciclagem de pH e tratamento com solução de 0,4\% de NaF (Ortho Gard, ColgatePalmolive®). Os Grupos 2 e 3 sofreram ciclagem de pH com soluções de desmineralização e remineralização em pH de 4,3 e 7,0 respectivamente, com ciclos de desmineralização (6 horas) e remineralização (17 horas), durante 15 dias. Os corpos de prova foram submetidos ao teste de resistência de união ao cisalhamento e remanescente adesivo (IRA). Espécimes de cada grupo $(\mathrm{n}=3)$ foram analisados qualitativamente por microscopia eletrônica de varredura (MEV). 0 teste de Kruskal-Wallis foi utilizado para avaliar a resistência ao cisalhamento e o teste exato de Fisher para avaliação do IRA, adotando nível de significância de 5\%. Resultado: Os resultados não encontraram diferença significativa entre os três grupos quanto à força de cisalhamento $(p=0,2679)$. Diferença significativa foi encontrada no IRA $(p=0,0199)$. A frequência de IRA 1 foi de 55\% no grupo 1, 90\% no grupo 2 e $80 \%$ no grupo 3 . A análise em MEV mostrou diferença entre o esmalte e a área de colagem submetida ao cisalhamento. Grupo 2 apresentou alteração estrutural na superfície do esmalte adjacente à área de colagem, e o Grupo 3 apresentou esmalte com característica semelhante ao do Grupo 1 na área que foi submetida à ciclagem de pH e NaF. Conclusão: Concluiu-se que não houve influência do flúor na resistência ao cisalhamento de braquetes. 0 uso de soluções fluoretadas, ainda que em baixa concentração, preveniu o aparecimento de áreas desmineralizadas e lesões de manchas brancas.
\end{abstract}

Descritores: Desmineralização dental; fluoreto de sódio; resistência ao cisalhamento; odontologia; ortodontia.

\begin{abstract}
Introduction: Fluoride is considered a key element in the remineralization process of tooth enamel. Objective: To evaluate the influence of a topical solution of sodium fluoride $(\mathrm{NaF})$ on the shear bond strength of orthodontic brackets and white spot lesions formation. Material and method: Sixty bovine teeth were divided into three groups $(n=20)$. Group 1 (Control): shear bond strength; Group 2: shear bond strength after $\mathrm{pH}$ cycling; Group 3: shear bond strength after $\mathrm{pH}$ cycling and treatment with $0.04 \% \mathrm{NaF}$ solution. Groups 2 and 3 underwent $\mathrm{pH}$ cycling with demineralizing (6hs) and remineralizing (17hs)
\end{abstract}


solutions at pH of 4.3 and 7.0 respectively for 15 days. The specimens were submitted to the shear bond strength and the Adhesive Remnant Index was verified (ARI). The specimens of each group ( $n=3$ ) were qualitatively analyzed by means of Scanning Electron Microscopy (SEM). Kruskal-Wallis test assessed the shear bond strength and Fisher's exact test evaluated ARI, with significance level of 5\%. Result: There was no significant difference among the three groups in shear bond strength ( $p=0.2679)$. Significant difference was found in ARI ( $p=0.0199)$. The frequency of ARI 1 was $55 \%$ in group $1,90 \%$ in group 2 , and $80 \%$ in group 3. SEM showed difference between the enamel and bonding. Group 2 showed structural change of the enamel surface, adjacent to the bond area; and group 3 showed enamel with characteristics similar to those of group 1. Conclusion: It was concluded that there was no NaF influence on the bracket shear bond strength and even in low concentrations it prevented the development of areas of demineralization of white spot lesions.

Descriptors: Tooth demineralization; sodium fluoride; shear bond strength; dentistry; orthodontics.

\section{INTRODUCTION}

One of the main aims in Dentistry is to diagnose and perform noninvasive treatment of noncavitated caries lesions, in an endeavor to prevent progression of the disease and preserve the integrity of healthy dental substrate. Non-invasive management of non-cavitated caries lesions involves various strategies of demineralized lesion control by using remineralizing agents or sealing them with resin materials ${ }^{1}$.

The appearance of white spot lesions during orthodontic treatment is highly prevalent ${ }^{2}$. Tooth enamel demineralization around the orthodontic brackets is mainly associated with bacterial plaque retention, culminating in a reduction in oral $\mathrm{pH}$ of the biofilm and consequent loss of mineral tooth structure, especially in patients who have inadequate oral hygiene habits ${ }^{3-}$ 5. The decline in oral hygiene, which frequently accompanies orthodontic treatment, may lead to increased risk for developing caries lesions ${ }^{6}$.

Dental caries is one of the most common childhood diseases. White spot lesions are the first visible evidence of cariogenic activity on the tooth tissue surface, caused by demineralization due to the action of bacterial products arising from dental biofilm when there is imbalance between the demineralization and remineralization cycles ${ }^{7}$. Enamel lesions have an aspect as an opaque white spot. The lesion area has many porous and appears opaque, white and the opacity increases with air drying8. If they are not remineralized, they develop into cavitations. These lesions generally occur in areas with food stagnation, bacterial biofilm retention; they are difficult to clean, and so are the orthodontic appliances ${ }^{7-9}$.

White spot lesions have the potential to develop as early as 4 weeks into orthodontic treatment ${ }^{10}$. They may lead to enamel cavitation if they are not remineralized with the purpose of paralyzing this process. The use of fluoride home-care products with low-concentration in a high-frequency is recommended during the dynamics of tooth remineralization to prevent cavity formation ${ }^{3}$. Therefore, it is important implementing preventive procedures to prevent the loss of dental structures. Fluoride is considered an important element in disease prevention in oral health on account of its prophylaxis of caries, introduced in soluble form. The fluorine ion is chemically fixed on both the mineral and organic enamel and dentin substance 9 . Its efficacy in the combat of dental caries has been proved, by means of topical application of different vehicles containing this ion ${ }^{4,9}$.

Remineralization is a process in which the tooth receives calcium and phosphate ions arising in the oral medium for filling the spaces present as a result of enamel demineralization. Fluoride is considered a key element in this process, but its capacity for promoting remineralization is limited by the availability of calcium and phosphate ions ${ }^{1}$. Fluoridated solutions are indicated for patients who are undergoing orthodontic treatment. When in low concentrations, these solutions can able to drastically reduce the risk of toxicity and even so, maintain the benefit of preventing demineralization of the teeth in oral medium ${ }^{11}$ without interfering in the bond strength of the orthodontic appliances ${ }^{12}$.

Therefore, the aim of this in vitro study was to evaluate the influence of a topical solution of $0.04 \%$ sodium fluoride on the shear bond strength and white spot lesions formation in the process of enamel demineralization associated with orthodontic brackets. 


\section{MATERIAL AND METHOD}

\section{Sample and De-remineralizing Solutions}

The study was approved by the Research Ethics Committee (040/2019).The research sample consisted of sixty bovine (incisor) teeth stored in a $0.01 \%$ Thymol solution and kept refrigerated until they were used. The test specimens were randomly divided into three groups $(\mathrm{n}=20)$. Group 1 (Control): shear bond strength; group 2: shear bond strength after $\mathrm{pH}$ cycling; and group 3: shear bond strength after $\mathrm{pH}$ cycling and sodium fluoride treatment.

The demineralization and remineralizing solutions were prepared according to the methodology of Toda, Featherstone12 (2008) for pH cycling. The demineralizing solution had $\mathrm{pH} 4.3$ and the remineralizing solution, $\mathrm{pH}$ 7.0. The $0.04 \% \mathrm{NaF}$ solution was acquired from Ortho Gard (Colgate-Palmolive, New York, USA).

\section{Orthodontic Bracket Bonding and Area of Analysis}

The methodology used for preparing the test specimens was carried out according to Ioannidis et al. ${ }^{13}$. Sixty bovine teeth were fixed and adapted to a cutting machine (model ELSAW, ElQuip ${ }^{\mathrm{TM}}$, São Paulo, SP, Brazil) with a diamond coated disc (model ER04003 HC 4 × 0.012 × 1/2, ERIOSTM, São Paulo, SP, Brazil), and were sectioned, separating the crown and roots from the teeth. The crowns were sectioned in the vestibular-lingual direction to obtain 60 fragments measuring $8 \mathrm{~mm} \mathrm{x}$ $8 \mathrm{~mm}$. They were flattened by means of a metallographic polishing machine PL V060 (Biopdi, São Carlos, SP, Brazil) to standardize the surfaces. The sample calculation was performed based on the effect sizes found in the literature $\mathrm{e}^{14,15}$ and ISO/TS $11405^{16}$ recommendations for this study design. The sample size of 60 teeth, 20 in each group, provided $80 \%$ test power $(\beta=0.20)$ to detect large effects $(\mathrm{f}=0.41)$ for shear bond strength and $\mathrm{w}=0.48$ for ARI, with a significance level of $5 \%(\alpha=0.05)$.

The vestibular surface of each test specimen was polished with silicon carbide water paper abrasive discs used consecutively, grit size of 180, 400 and 600 (3M do Brasil Ltda., Sumaré, SP, Brazil), in order to expose the same enamel area for bracket bond3,14-16. The flattest portion of the vestibular surface of each crown was maintained as parallel as possible, without exposing the dentin, fixed in orthophthalic resin (Equifibras, Salvador, BA, Brazil), polishing and placed in an ultrasonic bath L-200 (Schuster ${ }^{\mathrm{TM}} \mathrm{Ltda}$ ) for 10 minutes to remove possible polishing residues.

The area that was submitted to treatment was delimited with adhesive Silver Tape (3M, Brazil) with $6.5 \mathrm{~mm}$ in diameter. The orthodontic bonding was performed, which still left a free area at the margin of this bracket of $1 \mathrm{~mm}$, where topical fluoride application was made, and subsequent $\mathrm{pH}$ cycling was performed. The area beyond this circumference was isolated with impermeable nail varnish ${ }^{8,13}$.

The sample were submitted to acid attack ( $37 \%$ phosphoric acid) for 15 seconds, washed for 30 seconds, and dried with jet of air for 20 seconds, in accordance with the manufacturer's instructions. A thin, uniform layer of the primer Transbond XT (3M Unitek, Monrovia, USA) was applied on the tooth surface, with a microbrush. A syringe was used to apply a small quantity of Adhesive Transbond XT (3M Unitek, Monrovia, USA) on the bracket base (3M Unitek, Monrovia, USA).

Roth standard metal orthodontic bracket, slot 0.022" (Morelli Roth Max, Sorocaba, São Paulo, Brazil) for maxillary central incisors, was positioned on the tooth surface and excess of adhesive was removed from around the bracket base. The surfaces were light cured at a distance of $5 \mathrm{~mm}$ for 10 seconds on each bracket side, with light intensity of $>500 \mathrm{~mW} / \mathrm{cm}^{2}$ (Dabi Atlante ${ }^{\mathrm{TM}}$, Ribeirão Preto, Brazil), according to the manufacturer's instructions (3M"M $\mathrm{M}^{\mathrm{TM}}$ Minessota, USA) ${ }^{14}$.

\section{The pH Cycling and Topical Fluoride Treatment}

The $\mathrm{pH}$ cycling process occurred after preparing the test specimens and performing bonding of the orthodontic appliances. The demineralization and remineralizing solution (de-rem) was 
used for immersing the test specimens for 15 days of $\mathrm{pH}$ cycling. The de-rem solutions had a $\mathrm{pH}$ of 4.3 and $\mathrm{pH} 7.0$ respectively; the specimens were submitted to cycles of demineralization (6 hours) and remineralization (17 hours) ${ }^{12,17}$. During $\mathrm{pH}$ cycling, the three groups were stored in individual receptacles and kept in an oven at $37^{\circ}$ C. Group 1 was kept in distilled water at pH 7.0.

The topical fluoride treatment (Group 3) was performed with $0.04 \%$ Ortho-Gard sodium fluoride solution by immersion, using $10 \mathrm{ml}$ in each specimen for 60 seconds, during 15 days, interspersed with the de-rem process, simulating topical applications daily mouth washes, as recommended by the manufacturer (Colgate-Palmolive, New York, USA) ${ }^{12}$.

\section{Mechanical Shear Bond Strength Test and Measurement of Adhesive Remnant Index}

The shear bond strength test was performed in a universal test machine EMIC (model DL 2000, São José dos Pinhais, Paraná, Brazil), using an adapter to position the test specimens, with the parallel downward direction to the surface at the base of the brackets. The speed of 0.5 $\mathrm{mm} /$ min was maintained until rupture occurred between the bracket and test specimen, with force recorded in Newtons (N) and converted into MegaPascal (MPa), according to the area of the bracket 14,15 .

The teeth were submitted to evaluation of the adhesive remnant index (ARI). The vestibular surface of each test specimen was evaluated under a stereoscopic lens (Carl Zeiss, Göttingen, Germany) in order to quantify the Remaining Adhesive Index (ARI) as recommended by Årtun, Bergland ${ }^{18}$. The ARI scores were obtained by means of the following list: $0=$ no quantity of material adhered to the enamel surface; $1=$ less than $50 \%$ of material adhered to the enamel surface; $2=$ over $50 \%$ of material adhered to the enamel surface, and $3=100 \%$ of material adhered to the enamel surface.

\section{Analysis by Scanning Electron Microscopy}

The Scanning Electron Microscopy (SEM) procedure was performed with a TESCAN microscope, model VEJA 3 LMU with secondary electron detector. Three test specimens were randomly selected from each group, totaling nine test specimens that were qualitatively analyzed. In the test, a tension of fifteen kilovolts $(15 \mathrm{Kv})$ and $500 \times$ of magnification of the images was used, which corresponded to tooth/bond area interface ${ }^{19}$.

\section{Statistical Analysis}

The distribution of the shear bond strength data (MPa) did not meet the assumptions of the analysis of variance (ANOVA). Therefore, the data were submitted to nonparametric KruskalWallis statistical analysis. The variable Adhesive Remnant Index (ARI) was analyzed using the Exact Fisher test. All the analyses were performed using the software R (R Core Team, 2018), with significance of $5 \%$.

\section{RESULT}

\section{Shear Bond Strength and Adhesive Remnant Index}

Table 1 presents the median, minimum and maximum values of shear bond strength (MPa), according to the group. It was possible to observe that no significant differences were found among the three groups $(\mathrm{p}=0.2679)$. 
Table 1. Median (minimum - maximum) of shear bond strength (MPa), according to the group

\begin{tabular}{cc}
\hline Groups & Shear bond strength (MPa) \\
\hline Group 1 - Control & $6.86(2.00-19.52)$ \\
Group 2 - Without sodium fluoride & $5.90(0.95-21.52)$ \\
Group 3 - With sodium fluoride & $9.29(0.95-23.43)$ \\
\hline
\end{tabular}

p-valor $=0.2679$, Kruskal-Wallis test

Significant association ( $\mathrm{p}=0.0199$ ) was found in ARI and the groups (Table 2 and Figure 1 ). When evaluating the ARI, $55.0 \%$ of the specimens in the group 1 had ARI $=0$. This value was equal to $90 \%$ in the group 2 with $\mathrm{pH}$ cycling without sodium fluoride; and $80 \%$ in the group 3 submitted to $\mathrm{pH}$ cycling, with $0.04 \%$ sodium fluoride solution.

Furthermore, relative to ARI $=3$ ( $100 \%$ of material adhered), $15 \%$ of the test specimens of the group 1 were observed to show this behavior. Whereas, $10.0 \%$ showed ARI=3 in the group 2 without the addition of sodium fluoride; and $0.0 \%$ in the group 3 with sodium fluoride. When ARI $=0$ and IRA=1 were evaluated together; that is, less than $50 \%$ of material adhered, the group 1 was noted to show $75 \%$ of the test specimens with ARI $\leq 1$. This percentage was $90.0 \%$ in group without fluoride and $100.0 \%$ in group with fluoride.

Table 2. Frequency (number and percentage) of Adhesive Remnant Index (ARI), according to the group

\begin{tabular}{ccccc}
\hline \multirow{2}{*}{ Groups } & \multicolumn{4}{c}{ Adhesive Remnant Index (ARI) } \\
\cline { 2 - 5 } & $\mathbf{0}$ & $\mathbf{1}$ & $\mathbf{2}$ & $\mathbf{3}$ \\
\hline Group 1 - Control & $11(55.0 \%)$ & $4(20.0 \%)$ & $2(10.0 \%)$ & $3(15.0 \%)$ \\
Group 2 - Without sodium fluoride & $18(90.0 \%)$ & $0(0.0 \%)$ & $0(0.0 \%)$ & $2(10.0 \%)$ \\
Group 3 - With sodium fluoride & $16(80.0 \%)$ & $4(20.0 \%)$ & $0(0.0 \%)$ & $0(0.0 \%)$ \\
\hline
\end{tabular}

p-value $=0.0199$, Exact Fisher test.
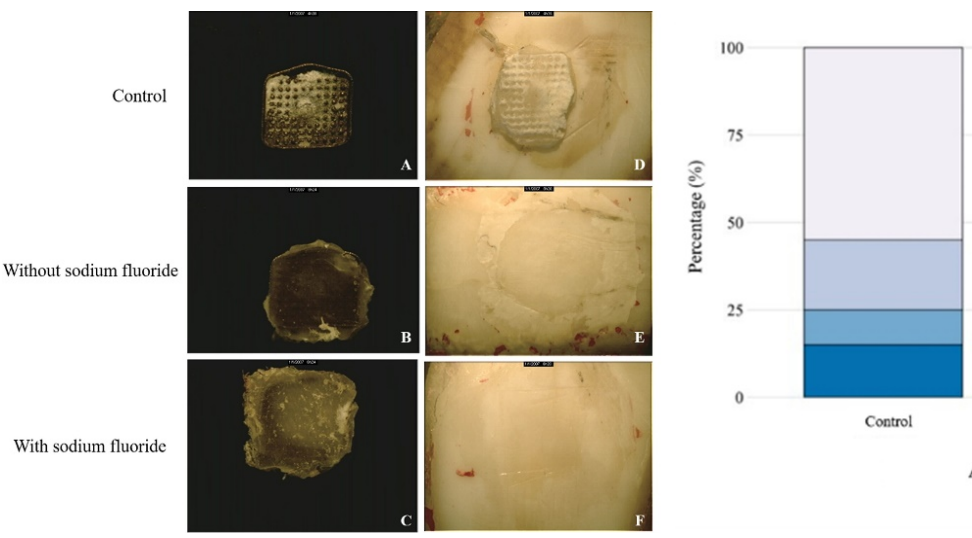

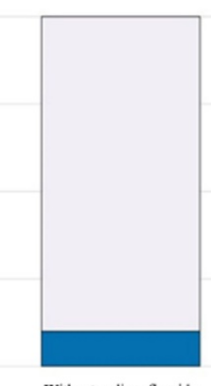

Without sodiun fluoride

Adhesive Remnant Index $\square 0 \square 1 \square 2 \square 3$

;p-value $=0.0199$

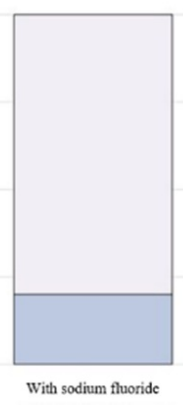

G

Figure 1. Photomicrograph of region of bracket base (A, B and $C)$ and bovine enamel (D, $E$ and $F)$ under stereoscopic lens (7×) shear bond strength test for verification of Adhesive Remnant Index (ARI). Graph shows ARI Score Classifications (G).

\section{Scanning Electronic Microscopy}

Group 1 (Figure 2A) showed the difference between the free enamel and bracket bonding area. There was a structural change (demineralization) in acid etching area of tooth enamel surface (\# area). This could be seen in the images obtained in the region of the interface between the free enamel and bonding area.

Group 2 (Figure 2B), which was submitted to $\mathrm{pH}$ cycling, showed a demineralization on enamel surface to an even greater extent. The image shows that $\mathrm{pH}$ cycling attained levels that 
were sufficiently high to form cavitated lesions in the enamel (\# area) adjacent to the orthodontic bracket bonding area (* area). Fluoride topic in group 3 (Figure 2C) was capable of remineralizing the enamel surfaces (\# area), in which the enamel in this group was shown to be similar to that of the group 1.

In summary, the images obtained by SEM showed significant difference between the area of enamel that was submitted to $\mathrm{pH}$ cycling (\# area) in group 2, and the area of enamel under bonded bracket (*area).
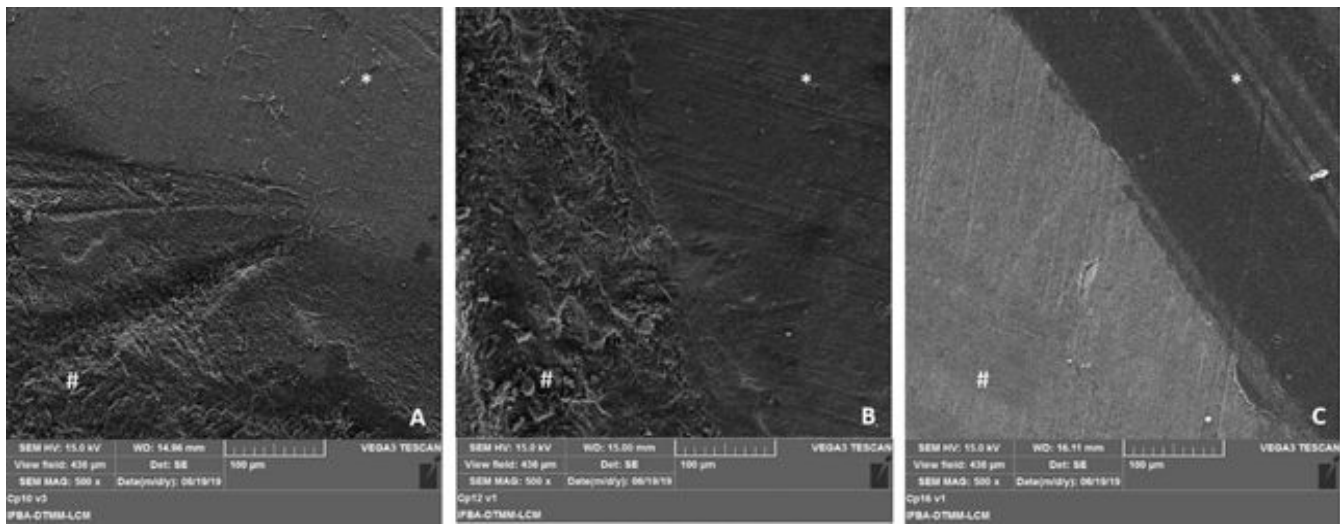

Figure 2. Photomicrograph of area of interface between enamel and area of bracket bonding to test specimens examined by SEM (500x). (A) group 1. (B) group 2. (C) group 3. \# area of free enamel. * area of enamel under bonded bracket.

\section{DISCUSSION}

Dental caries continues to be a public health problem ${ }^{1}$. Orthodontic treatment with fixed appliances has been associated with adverse effects on the teeth and adjacent structures, among these, the appearance of incipient caries lesions ${ }^{20}$. The present study sought to evaluate the in vitro effect of the structural change (demineralization) of enamel surface around the brackets after variations in $\mathrm{pH}$. This effect is a current concern of orthodontists, due to the high prevalence of the appearance of white spot lesions around brackets, a fact that could compromise the final esthetic result of treatment and frustrates patient expectation. The purpose of the presence of fluoride is to prevent the loss of mineral structure into the oral environment. The cariostatic effect occurs due to the formation of a calcium fluoride layer $\left(\mathrm{CaF}_{2}\right)$ which dissolves and releases ions by $\mathrm{pH}$ reduction to prevent that the underlying enamel is reached ${ }^{21}$. Furthermore, the influence of fluoride on the shear bond strength of orthodontic resins under cariogenic challenge is not well known ${ }^{15}$. The usual concentration of $1450 \mathrm{ppm}$ found in toothpastes has been insufficient to have a mechanical influence on the shear strength ${ }^{22}$. The present study we used a $0.04 \% \mathrm{NaF}$ topic fluoride and the null hypothesis that this fluoride would not have any influence on the shear bond strength was also confirmed.

In the literature, there are not clear guidelines about shear strength limits, but in fact a good orthodontic biomaterial should allow good adhesion in order to sustain masticatory forces, with minimum bond strength of 5-10 MPa. Additionally, adhesion forces should not be too strong in order to avoid substrate loss after debonding (40-50 MPa). Therefore, the ideal orthodontic biomaterial should have shear bond strength included in the interval of 5-50 MPa, even if these limits are mostly theoretical ${ }^{23}$.

When the adhesive remnant index was evaluated, the bond mechanism was found to undergo influence of the de-rem process. In this study, the presence of adhesive on enamel was the highest in group 1, and the fluoride solution treatment after $\mathrm{pH}$ cycling, did not improve the 
quality of bonding orthodontic brackets to the treated enamel surface ${ }^{5}$. The apatite of enamel undergoes fewer substitutions of mineral than bone and dentin, and was expected that the incorporation of fluoride could improve the physical properties of enamel on the shear strength ${ }^{24}$.

Orthodontic appliances lead to physical changes in the microbial environment. The increase in proliferation of the facultative bacterial population, including Streptococcus mutans, leads to a reduction in $\mathrm{pH}$, which could lead to the development of white spot lesions, and eventually, cavitated caries lesions that extend into dentin ${ }^{6,10}$. For the induction of caries, the dynamics of $\mathrm{pH}$ cycling by immersion in de-rem solutions is the closest in vitro method for simulating the development of these lesions in vivo. In addition, in those circumstances, fluorides play an important role in caries inhibition, due to the proximity of areas with biofilm accumulation and SEM is a good method for evaluating the dynamics of the physico-chemical states of de-rem behavior of enamel after exposure to acidic solutions and fluorides ${ }^{25}$.

In the present study, the images obtained by SEM clearly illustrated that the enamel surface in bonding area, in groups induced by the $\mathrm{pH}$ cycling, was capable of maintaining itself almost intact without other auxiliary means of remineralization, such as saliva or water supply, or even fluoridated agents. Even more, the SEM records of the group 3 tooth/bonding area interface remained similar to those of group 1, which proved the importance of fluoride in preventing the appearance of active white spot lesions, and consequently in the maintenance of integrity of the orthodontic patient's oral health ${ }^{26,27}$.

It is important to note that the prevention of white spot lesions during orthodontic treatment with brackets must be carried out with the correct use of a toothbrush and dental floss ${ }^{28}$. In addition, patients with low levels of oral hygiene need to be submitted to periodic professional prophylaxis ${ }^{29}$. This is an in vitro study and should be interpreted with caution, however, it demonstrated that the de-rem condition can influence the quality of brackets bonding; and fluoride, even in low concentration, does not interfere in mechanical strength.

Topical fluoride solutions in low concentrations can be safer for patients, particularly youngsters, because they reduce possible risks of intoxication by ingestion ${ }^{11}$. The absence of direct influence of fluoride on the shear bond strength may suggest new studies in this area to develop techniques for preventing the appearance of white spot lesions in patients who make use of orthodontic brackets.

\section{CONCLUSION}

Sodium fluoride $(0.04 \% \mathrm{NaF})$ did not influence the mechanical shear bond strength, and even in low concentrations was prevented the development of new areas of demineralization of white spot lesions.

\section{REFERENCES}

1. Elkassas D, Arafa A. Remineralizing efficacy of different calcium-phosphate and fluoride based delivery vehicles on artificial caries like enamel lesions. J Dent. 2014 Apr;42(4):466-74.

http://dx.doi.org/10.1016/j.jdent.2013.12.017. PMid:24412586.

2. Akin M, Basciftci FA. Can white spot lesions be treated effectively? Angle Orthod. 2012 Sep;82(5):7705. http://dx.doi.org/10.2319/090711.578.1. PMid:22356705.

3. Caldeira EM, Fidalgo TKS, Passalini P, Marquezan M, Maia LC, Nojima MCG. Effect of fluoride on tooth erosion around orthodontic brackets. Braz Dent J. 2012 Oct;23(5):581-5.

http://dx.doi.org/10.1590/S0103-64402012000500019. PMid:23306238. 
4. Cury JA, Oliveira BH, Santos AP, Tenuta LM. Are fluoride releasing dental materials clinically effective on caries control? Dent Mater. 2016 Mar;32(3):323-33. http://dx.doi.org/10.1016/j.dental.2015.12.002. PMid:26777115.

5. Khoroushi M, Kachuie M. Prevention and treatment of white spot lesions in orthodontic patients. Contemp Clin Dent. 2017 Jan-Mar;8(1):11-9. http://dx.doi.org/10.4103/ccd.ccd_216_17. PMid:28566845.

6. Richter AE, Arruda AO, Peters MC, Sohn W. Incidence of caries lesions among patients treated with comprehensive orthodontics. Am J Orthod Dentofacial Orthop. 2011 May;139(5):657-64. http://dx.doi.org/10.1016/j.ajodo.2009.06.037. PMid:21536209.

7. Paula AB, Fernandes AR, Coelho AS, Marto CM, Ferreira MM, Caramelo F, et al. Therapies for white spot lesions-a systematic review. J Evid Based Dent Pract. 2017 Mar;17(1):23-38. http://dx.doi.org/10.1016/j.jebdp.2016.10.003. PMid:28259311.

8. Nassur C, Pomarico L, Maia LC. Reliability analysis of two methods for measuring active enamel demineralization: an in vitro study. Eur J Dent. 2013 Apr;7(2):159-64. http://dx.doi.org/10.4103/1305-7456.110157. PMid:24883020.

9. Zampetti P, Scribante A. Historical and bibliometric notes on the use of fluoride in caries prevention. Eur J Paediatr Dent. 2020 Jun;21(2):148-52. PMid:32567947.

10. Srivastava K, Tikku T, Khanna R, Sachan K. Risk factors and management of white spot lesions in orthodontics. J Orthod Sci. 2013 Apr;2(2):43-9. http://dx.doi.org/10.4103/2278-0203.115081. PMid:24987641.

11. Cury JA, Ricomini-Filho AP, Berti FLP, Tabchoury CPM. Systemic effects (risks) of water fluoridation. Braz Dent J. 2019 Sep-Oct;30(5):421-8. http://dx.doi.org/10.1590/0103-6440201903124. PMid:31596325.

12. Toda S, Featherstone JD. Effects of fluoride dentifrices on enamel lesion formation. J Dent Res. 2008;87(3):224-7. http://dx.doi.org/10.1177/154405910808700303. PMid:18296604.

13. Ioannidis A, Papageorgiou SN, Sifakakis I, Zinelis S, Eliades G, Eliades T. Orthodontic bonding and debonding induces structural changes but does not alter the mechanical properties of enamel. Prog Orthod. 2018 May;19(1):12. http://dx.doi.org/10.1186/s40510-018-0211-7. PMid:29732491.

14. Torres VS, Lima MJP, Valdrighi HC, Campos EJ, Santamaria-Jr M. Whitening dentifrices effect on enamel with orthodontic braces after simulated brushing. Eur J Dent. 2020 Feb;14(1):13-8. http://dx.doi.org/10.1055/s-0039-3403474. PMid:31955402.

15. Fidalgo TK, Pithon MM, Santos RL, Alencar NA, Abrahão AC, Maia LC. Influence of topical fluoride application on mechanical properties of orthodontic bonding materials under pH cycling. Angle Orthod. 2012 Nov;82(6):1071-7. http://dx.doi.org/10.2319/101711-644.1. PMid:22439766.

16. International Organization for Standardization - ISO. ISO/TS 11405:2015: Dentistry - testing of adhesion to tooth structure. Geneva: ISO; 2015 [cited 2021 July 28]. Available from: https://www.iso.org/standard/62898.html.

17. Montasser MA, El-Wassefy NA, Taha M. In vitro study of the potential protection of sound enamel against demineralization. Prog Orthod. 2015;16(1):12. http://dx.doi.org/10.1186/s40510-015-00802. PMid:26061985.

18. Årtun J, Bergland S. Clinical trials with crystal growth conditioning as an alternative to acid-etch enamel pretreatment. Am J Orthod. 1984 Apr;85(4):333-40. http://dx.doi.org/10.1016/00029416(84)90190-8. PMid:6231863.

19. Daud A, Gray G, Lynch CD, Wilson NHF, Blum IR. A randomised controlled study on the use of finishing and polishing systems on different resin composites using 3D contact optical profilometry and scanning electron microscopy. J Dent. 2018 Apr;71:25-30. http://dx.doi.org/10.1016/j.jdent.2018.01.008. PMid:29360492. 
20. Tasios T, Papageorgiou SN, Papadopoulos MA, Tsapas A, Haidich AB. Prevention of orthodontic enamel demineralization: a systematic review with meta-analyses. Orthod Craniofac Res. 2019 Nov;22(4):22535. http://dx.doi.org/10.1111/ocr.12322. PMid:31081584.

21. Leódido GR, Fernandes HO, Tonetto MR, Presoto CD, Bandéca MC, Firoozmand LM. Effect of fluoride solutions on the shear bond strength of orthodontic brackets. Braz Dent J. 2012;23(6):698-702. http://dx.doi.org/10.1590/S0103-64402012000600012. PMid:23338263.

22. Barros ÉL, Pinto SC, Borges AH, Tonetto MR, Ellwood RP, Pretty I, et al. Toothpaste prevents debonded brackets on erosive enamel. ScientificWorldJournal. 2015;2015:468582. http://dx.doi.org/10.1155/2015/468582. PMid:25879058.

23. Scribante A, Contreras-Bulnes R, Montasser MA, Vallittu PK. Orthodontics: bracket materials, adhesives systems, and their bond strength. BioMed Res Int. 2016;2016:1329814. http://dx.doi.org/10.1155/2016/1329814. PMid:27818996.

24. Abou Neel EA, Aljabo A, Strange A, Ibrahim S, Coathup M, Young AM, et al. Demineralizationremineralization dynamics in teeth and bone. Int J Nanomedicine. 2016 Sep;11:4743-63. http://dx.doi.org/10.2147/IJN.S107624. PMid:27695330.

25. Filho MV, Martins SH, Valdrighi HC, Vedovello AS, Kuramae M, Lucato AS, et al. Evaluation of bond orthodontics brackets using different adhesive systems after a cariogenic challenge. J Contemp Dent Pract. 2010 Jan;11(1):E041-8. PMid:20098965.

26. Sivapriya E, Sridevi K, Periasamy R, Lakshminarayanan L, Pradeepkumar AR. Remineralization ability of sodium fluoride on the microhardness of enamel, dentin, and dentinoenamel junction: An in vitro study. J Conserv Dent. 2017 Mar-Apr;20(2):100-4. http://dx.doi.org/10.4103/JCD.JCD_353_16. PMid:28855756.

27. Rao R, Jain A, Verma M, Langade D, Patil A. Comparative evaluation of remineralizing potential of Fluoride using three different remineralizing protocols: an in vitro study. J Conserv Dent. 2017 NovDec;20(6):463-6. http://dx.doi.org/10.4103/JCD.JCD_203_17. PMid:29430102.

28. Santos JB, Pereira LC, Neves JG, Pithon MM, Santamaria-Jr M. Can text messages encourage flossing among orthodontic patients? Angle Orthod. 2021 Sep;91(5):650-5. http://dx.doi.org/10.2319/012121-61.1. PMid:33946101.

29. Lopatiene K, Borisovaite M, Lapenaite E. Prevention and treatment of white spot lesions during and after treatment with fixed orthodontic appliances: a systematic literature Review. J Oral Maxillofac Res. 2016 Jun;7(2):e1. http://dx.doi.org/10.5037/jomr.2016.7201. PMid:27489605.

\section{CONFLICTS OF INTERESTS}

The authors declare no conflicts of interest.

\section{${ }^{*}$ CORRESPONDING AUTHOR}

Milton Santamaria-Jr, Heloisa Cristina Valdrighi, FHO - Fundação Hermínio Ometto, Centro Universitário, Programa de Pós-graduação em Ortodontia, Av. Dr. Maximiliano Baruto, 500, 13607-339 Araras - SP, Brasil, e-mail: miltonsantamariajr@gmail.com; heloisavaldrighi@gmail.com

Received: July 28, 2021

Accepted: November 10, 2021 